\title{
The Future of the U.S. Diplomatic Representations after the Case of Benghazi: The Brittle Relationship between Security and Diplomacy
}

\section{Alberto Priego}

To cite this article: Alberto Priego (2017) The Future of the U.S. Diplomatic Representations after the Case of Benghazi: The Brittle Relationship between Security and Diplomacy, The International Journal of Intelligence, Security, and Public Affairs, 19:2, 92-111

To link to this article: http://dx.doi.org/10.1080/23800992.2017.1336396

曲 Published online: 18 Jul 2017.

Submit your article to this journal 지

LII Article views: 2

Q View related articles $\sqsubset$

View Crossmark data \lceil 


\title{
The Future of the U.S. Diplomatic Representations after the Case of Benghazi: The Brittle Relationship between Security and Diplomacy
}

\author{
Alberto Priego (1) \\ Department of International Relations, Universidad Pontificia de Comillas, Madrid, Spain
}

\begin{abstract}
One of the conditions for the development of diplomacy is the existence of a peaceful climate. To create this, diplomatic missions and agents should enjoy some privileges and immunities granted by the receiving state. Since the late 1970s, the emergence of violent non-state groups is changing the conception of security, and this transformation has a direct effect on diplomatic relations. We have selected three crises that span the relationship between diplomacy and security between diplomacy and security. The first one occurred in 1979 in Tehran, the second started in 1983 in the Lebanon finishing in East Africa 15 years later, and the last of these crises took place in Benghazi, with the attack on the American consulate in 2012. Each crisis has caused a shift in the paradigm of diplomatic security. The measures adopted by the U.S. Department of State to prevent future attacks, far from solving the problem, are threatening the future of diplomacy.
\end{abstract}

\section{ARTICLE HISTORY}

Received 21 December 2016 Revised 8 May 2017

Accepted 11 May 2017

\section{KEYWORDS}

Benghazi; Department of State; diplomacy;

intelligence; paradigm; security; terrorism; United States

\section{Introduction}

Over the last 30 years, the international society (Watson, 1987) has experienced significant changes, especially in the security field. ${ }^{1}$ The emergence of non-state-actors, the vanishing of the line between domestic and international security (Abad, 2015, p. 43) or the emergence of non-traditional threats (Buzan, 2007, p. 124) are just some of the elements that are transforming the international system.

Concerning diplomacy, ${ }^{2}$ the situation is not particularly different. At the beginning of the 1980s, because of the violence against diplomatic facilities, diplomats were forced to alter their traditional and daily working routines. Uncontrolled groups, weak or failed states, and terrorist organizations have completely transformed diplomacy, forcing Ministries of Foreign Affairs to rethink their role. Serious incidents such as the assault of embassies, the hostage-taking of diplomats, or the bombings targeted

CONTACT Alberto Priego apriego@comillas.edu Department of International Relations, Universidad Pontificia de Comillas, Universidad Comillas 3, Madrid 28049, Spain.

Color versions of one or more of the figures in the article can be found online at www.tandfonline.com/usip. 
against diplomatic facilities show us that diplomatic immunities and privileges are not sufficient in order to stand up to or repel current nontraditional threats.

The State Department has classified 30 countries at "highest risk or threat" for security (Rana, 2013, p. 67). In fact, since the late 1990s, security measures adopted by diplomatic delegations have increased exponentially. Check-points, insurmountable walls, or the militarization of security staff are only some examples of shifts that make the everyday work of diplomatic personnel more difficult.

Diplomatic immunities and privileges attributed to missions and diplomats do not seem to be enough to ensure a minimum of security to carry out their diplomatic work. The real problem is that such immunities were designed to deal with the actions of other states, whereas now the threats come from non-state actors (terrorists, mafias, etc.).

The most recent of these tragic episodes of violence occurred in the American Consulate in Benghazi. The American ambassador to Libya and three other members of the U.S. delegation were killed in an attack against the consular complex. The magnitude of the Benghazi terrorist attack, like those occurring in Beirut, Nairobi, and Dar es Salaam, will entail a paradigm shift in the security of diplomatic facilities.

This article will try to explain the changes that have occurred in the security of (American) diplomatic missions from the beginning of the 1980s. Those responsible for diplomatic security are looking for accurate answers to face up to new challenges and threats (new terrorist groups, transnational crime, failed states, etc.). Indeed, it is the case that, in the current international situation, diplomacy is more necessary than ever, while at the same time diplomacy is riskier now than in any other period.

For that reason, my hypothesis is that the assault on the Benghazi Consulate will mean a significant change in the permanently tense relationship between security and diplomacy. As happened after the attacks in Tehran, Beirut, and East Africa, the State Department opened a period of reflection (commission of inquiry) which concluded with the adoption of extraordinary security measures. While these measures may prevent further terrorist attacks, at the same time, in most of the cases, they could cause serious difficulties in the development of the functions conferred to diplomatic missions as in the 1961 Vienna Convention.

First, I will make an analysis of the protection of diplomatic missions and their agents. Secondly, we will review major terrorist attacks against American diplomatic premises. Thirdly, we will focus on the case of Benghazi and how these attacks will determine the relations between security and diplomacy for the future (Quainton, 2015, p. 29). 


\section{Protection of diplomatic missions and agents}

Due to the nature of diplomacy itself, both missions and agents must enjoy special protection to ensure their safety and independence from pressures that may be exerted by the receiving state (Berridge, 2010, p. 109). The 1961 Vienna Convention on Diplomatic Relations (United Nations, 1961) and the 1963 Convention on Consular Relations (United Nations, 1963) recognized these privileges and immunities. Articles 20-25 of the 1961 Vienna Convention deal with immunities and privileges of diplomatic missions, and Articles 29-33 focus on the protection of diplomatic agents (United Nations, 1961). Although there are some significant cases where these privileges and immunities have been violated, it must be said that, normally, from the moment that the establishment of diplomatic relations is agreed, there is strong respect for those privileges and immunities. It is precisely this privileged position which ensures that diplomats respect the law as well as the local customs of the receiving state. Therefore, the relationship established between sending and receiving states must be clear and respectful on both sides. ${ }^{3}$

However, since the late 1970s, international society has witnessed the emergence of non-state actors, who cannot be considered as respectful as states are. Although these new members of international society are not considered subjects of international law, these non-state actors hold great importance for the security of diplomatic facilities. We are referring mainly to more or less organized groups, which are openly violent and seek to alter the peaceful life of missions and diplomatic agents.

Unfortunately, in the last 40 years, there have been many episodes of violence against diplomats. However, some of them are particularly significant. Notable examples include the Iranian Students of Theology, in 1979, the Tupac Amaru (Pigman, 2010, p. 21) militants in Peru, in 1999, and, more recently, the Million Man Parade in post-Mubarak Egypt, in 2013.

Although in most of the cases, the receiving state has nothing to do with these attacks, its obligation-established in the Vienna Conventions of 1961 (United Nations, 1961) and 1963 (United Nations, 1963) - is to protect the diplomatic missions under all circumstances. According to the Vienna Convention (United Nations, 1961), there is no possibility of failing to protect the diplomatic corps unless the receiving state declares itself unable to control the situation. That was the situation in Lebanon in the '80s, but it is unlikely to be frequent, as it would imply that the state has ceased to exist. In other words, in such situation, the state would be losing one of the reasons for its existence and could be considered as a failed, failing, or, at least, weak state.

If we focus on the specific case of assault on the Benghazi Consulate, many analysts conclude that the Arab Spring has been a complete failure, especially in Libya. The post-Gaddafi Libya is not able to guarantee a minimum security for diplomatic missions accredited in the country. Security in 
Libya is not only fragmented but has passed into the hands of warlords. It could be said that the Northern African country has moved to a pre-state phase where central authority has no control over the territory. Therefore, although half of the International Society (104 members of the UN) has recognized the National Transition Council as the legitimate government of Libya, states like Brazil, Ecuador, and Zimbabwe have decided not to recognize the new Libyan regime.

The current situation in Libya is chaotic. The lack of central authority, meaning the lack of a government, has created a situation of generalized violence where diplomats have to overcome significant obstacles to accomplish their task. As an example of this situation, and according to Eric A. Nordstrom, Regional Security Officer in Tripoli, the Benghazi terrorist attack will stand for a turning point in the protection of diplomatic missions as did the attacks on Lebanon in 1983 and on Kenya and Tanzania in 1998. In fact, Secretary of State Hillary Clinton described the case of Benghazi as a "systemic breakdown," and she stressed the need to increase security in diplomatic missions.

\section{Security, terrorism, and U.S. diplomacy}

In the past 60 years, the United States has held international leadership on five continents. This position has caused the United States in general, and its diplomatic premises in particular, to become the target of numerous terrorist attacks. The first attack occurred in Vietnam in 1965, and the last serious episode was the attack on the Consulate of Benghazi.

The history of these attacks against American diplomatic premises allows us to identify three major milestones: Tehran in 1979, Beirut in 1983, and Nairobi together with Dar es Salaam in 1998. ${ }^{4}$ These attacks have given rise to a paradigm shift (Figure 1) in the protection of diplomatic facilities and agents. This paradigm shift (Buzan \& Hansen, 2009, pp. 39-44) has been marked by the following sequence of events:

(1) First, a terrorist attack, that put in question the security of diplomatic missions, occurs.

(2) Secondly, due to the pressure exerted by public opinion, a commission of inquiry analyzes the attack and publishes a report where different experts propose extraordinary security measures to adopt in the future.

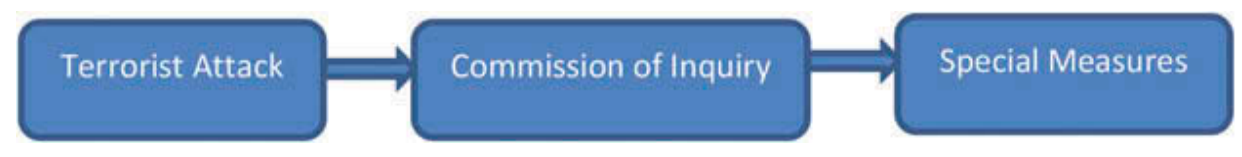

Figure 1. Paradigm shift. 


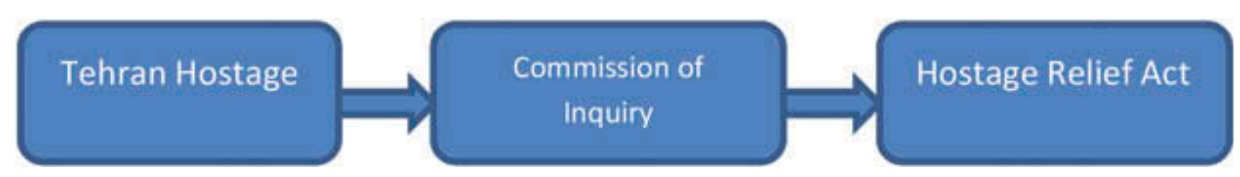

Figure 2. First paradigm shift.

(3) Thirdly, the State Department adopts these proposed security measures but they obstruct the performance of the main functions of diplomacy.

First paradigm shift: The assault on the U.S. Embassy in Tehran in 1979 and the subsequent taking of 53 American citizens (Houghton, 2013) fostered the approval of the Hostage Relief Act in 1980. This cause-effect relationship can be considered the first paradigm shift (Figure 2) in the safety of diplomatic and consular offices because before the siege of the U.S. Embassy in Tehran, a similar action to protect U.S. interests seemed unthinkable.

Second paradigm shift: The continuous attacks against American interests in Lebanon in the 1980s roused fears. However, the trigger element was the bombing of the American Embassy in Beirut (1983). This attack reached such dimensions that a commission of inquiry was established and the Inman Report $^{5}$ was published. The report proposed some recommendations to preserve the physical integrity of the American diplomats. ${ }^{6}$

Thirteen years after the publication of the Inman report, the United States suffered another attack against its embassies in Nairobi and Dar es Salaam. These two terrorist attacks marked a new turning point in the security of diplomatic facilities. As happened with the attacks in Lebanon, the events were analyzed by a commission of inquiry that produced the Crowe Report. ${ }^{7}$

Unfortunately, Nairobi and Dar es Salaam were not the first attacks against an American Embassy. However, these attacks showed up new elements that caused a Copernican revolution in the understanding of the protection of the Foreign Service.

On the one hand, the attacks were perpetrated by $\mathrm{Al}$ Qaeda, a terrorist group that, unlike others, did not intend to achieve a tangible political objective (recognition of Palestine as a state, a Marxist Revolution, etc.). On the other hand, attacks in East Africa were incredibly more violent than any previous ones. This action led by Al Qaeda, perfectly organized, left 253 dead (Patman, 2012, p. 304) and 4,000 wounded. Finally, the United States started to face a seemingly invisible enemy without a clear structure, a reality they are unprepared to fight against. After that, Washington began to redesign both the defence of its diplomatic facilities and the role assigned to its embassies and consulates. In conclusion, the bombings in Kenya and Tanzania led the United States to a new change in the way Washington should protect its embassies and its diplomats. 
Under these circumstances, the State Department decided to rethink its diplomatic security policy missions, adopting a more defensive position to prevent new attacks. Many of the security mistakes that allowed the terrorists to destroy U.S. embassies in Kenya and Tanzania had already been identified by the independent panel chaired by Admiral Inman (1985). The Inman Report (Rowe, 1999, p. 4) stressed that 126 embassies (out of 262) did not meet the minimum security requirements, and therefore a complete reform of the diplomatic facilities was essential. The lack of funds for the security of the diplomatic personnel and facilities, and the difficulties of establishing "the new embassies," provided the conditions for the attacks against the U.S. embassies in East Africa.

For this reason, since the beginning of the 21st century, the State Department has been replacing its old diplomatic facilities with new buildings as every diplomatic post may be a potential target (Pillar, 2001, p. 24). This replacement policy can be identified as the second paradigm shift in diplomatic security (Figure 3). The main aim of this shift was to prevent new tragedies like those occurring in Kenya, Tanzania or Beirut (Booth \& Dunne, 2012 , p. 56). So the main question is what elements should be taken into account in the construction of future diplomatic buildings to avoid new terrorist attacks?

The Inman Report, which was based on two previous reports prepared by the Office of Foreign Buildings and the CIA, addressed three basic requirements that any diplomatic delegation must meet to prevent terrorist attacks:

- to meet the basic standards concerning quality and safety of the buildings as well as the external barriers (Inman, 1985, p. 8);

- the diplomatic building should not share any wall with any other building to ease the defence of the facilities; and

- the members of the Foreign Service should have full control over the whole building avoiding sharing the building with other tenants. ${ }^{8}$

If the Beirut bombings introduced new security standards in the construction of diplomatic buildings, the Kenya and Tanzania (Tan \& Ramakrishna, 2002, p. 101) incidents created a new model of construction (Standard Embassy Design) that marked the beginning of the new paradigm for diplomatic security. Standard Embassy Design introduced important elements of protection against external attacks, especially against car-bombs. The author

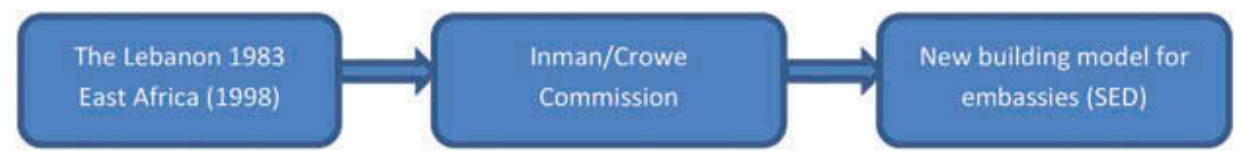

Figure 3. Second paradigm shift. 
of Standard Embassy Design was General Charles Williams, who was appointed as director of the Overseas Buildings Operation (OBO). What were the main features that the SED buildings had to comply with? (Loeffler, 2004, p. 69):

(1) The future diplomatic buildings should avoid historical places, business centers, and urban agglomerations because these areas are much more difficult to defend. Consequently, the United States has been moving its embassies from the city centers to suburban areas. The well-known case is the U.S. Embassy in London that will be relocated from Marble Arch to Nine Elms (Wandsworth) in 2017.

(2) Diplomatic and consular offices should be established in large areas of over 8,000 square meters. The aim is to have room enough to develop a complete professional and personal life. In particularly dangerous places in complicated countries, like Iraq or Libya, diplomatic premises are a real shelter and most of the diplomats do not leave the complex during the time that they are accredited. These fortifications greatly complicate the development of diplomatic functions. Some authors, like Loeffler (2007, p. 65), have even suggested whether these giants of cement can be called embassies.

(3) There should be some physical elements, such as fences or security perimeters, that are intended to provide greater security to the building. Finally, the establishments of water tanks at the compound entrance are also advised to deter the use of suicide vehicles. The building should also be provided with a self-pumping station and a generator to prevent attacks from outside (Kosowatz, 2002, p. 19).

(4) Other authors, like Campbell (2008, p. 61), have criticized the fact that these security measures are deeply focused on conventional violence, ignoring other threats like cyberterrorism or a weapons of mass destruction. Therefore, access to buildings must be supervised by both local troops and Regional Security Officers at all times. As stated in the Inman Report and confirmed in the Crowe Report, this element is crucial to maintaining the security of the embassy (Hanson, 2012, p. 202). Areas at greater risk are those open to the public: for instance, those designated for visa procedures or other requests.

One of the most controversial issues is that of local employees. In some cases, such as the U.S. delegation in Zagreb, the United States has come to implement an iris recognition system to avoid identification problems and identify intruders.

According to the size, the New Embassies can be classified as small, medium and large. However, regardless of the size, these New Embassies are all composed of two main buildings separated by an atrium. We find 
examples of these new models in the embassies of Beijing, Baghdad, Copenhagen, and Berlin, as well as in the American Consulate in Istanbul. Throughout the first decade of the 21st century, the State Department has been changing old embassies and consulates for these new models. While it is true that terrorist attacks have not stopped, security measures have been achieving their goal to reduce the number of casualties among diplomats. However, it would be a mistake to think that terrorism is not a problem for diplomacy anymore. On the contrary, because of the War on Terror and the use of diplomatic facilities as anti-terror headquarters, terrorist attacks against diplomatic missions have increased since the beginning of the 21 st century.

The latest serious incident took place in Libya, and again, the target was the American mission, specifically the Consulate in Benghazi. The impact of this attack has been so considerable that it threatens to become a new landmark in the security of American diplomatic missions. This is the motive that has led us to believe that Benghazi will promote the third paradigm shift in the relations between security and diplomacy.

\section{The Benghazi attack: The third paradigm shift}

Following the evolution of the cases of Tehran, Beirut, and East Africa, first we will analyze the attack itself, then the inquiry and finally the exceptional measures taken.

The United States and Libya have maintained a fluent bilateral relationship (Ferrell, 1975, pp. 734-735). Indeed, the United States was one of the first states that recognized Libya as an independent state under the sovereignty of King Idris. However, the relations between Washington and Tripoli have not been easy. When in 1969 Colonel Muammar Qadhaffi seized power (Paoletti, 2011, p. 315), the bilateral relationship reached a particularly difficult point. In December 1979, uncontrolled groups raided one of the buildings of the American Embassy, provoking the evacuation of the diplomatic staff and the subsequent closure of the mission. Previously, the United States had downgraded the rank of its diplomatic mission, which would remain at the third level until 2004, when Secretary of State Condoleezza Rice launched a diplomatic campaign to improve bilateral relations (Jentleson \& Whytock, 2005, p. 67). In June 2004, the United States opened a representative office in Tripoli, and two years later, diplomatic relations were fully restored (Busa, 2006, p. 13).

The Libyan civil war has caused a new, but probably deeper, crisis in diplomatic relations between Washington and Tripoli. Thus, on February 25, 2011, the State Department made the decision to evacuate its staff and entrust the protection of its interests to the delegation of Hungary. In July 2011, the United States recognized the Transitional National Council as the legitimate government of Libya. For that reason, in September, a group of 
American diplomats returned to Libya, accredited this time to the postQadhaffi government. This group included Ambassador Christopher Stevens (Pope, 2015, p. 67), a diplomat who deserves to be considered as a clear advocate of the democratization process in Northern Africa, in general, and in Libya, in particular. Previously, Ambassador Stevens had been accredited as Ambassador at Large to the National Transitional Council. He arrived in Benghazi, the city controlled by the rebels, from Greece, with the aim of restoring the diplomatic relations with the new government of Libya.

Throughout 2012, the situation in Eastern Libya became dangerous, particularly for foreign diplomats. In April, a convoy of the United Nations Special Envoy to Libya was attacked by a terrorist command. Fortunately, nobody suffered any injury. In May, the International Red Cross office in Benghazi was attacked by the Imprisoned Omar Abdul Rahman Brigades. In August, the Red Cross suspended its operations in Benghazi. In June, the British ambassador survived a terrorist attack, although two security officers who were protecting his convoy were seriously injured. Some days later, the Foreign Office withdrew all its diplomatic staff from Eastern Libya. Finally, the Embassy of Tunisia (Bullock, 2015, p. 16) was assaulted by a group linked to Ansar Al-Sharia.

It was widely known, that the U.S. Consulate in Benghazi was among the main targets for terrorists (Ros-Lehtinen, 2012, p. 46). In April, two former security guards threw a homemade bomb over the consulate fence. Some months later, in June, a group of about 40 people tried to storm the consulate fence. Although they did not achieve their goal, they dropped leaflets promising to strike again. A couple of days before the 11-S assault, a Libyan police officer was detained for taking pictures of the U.S. Consulate compound. Despite these clear signals, no measures were taken to prevent further tragedy

On September 11, an armed group stormed the U.S. Consulate in the Libyan city of Benghazi. Even today, the doubts outweigh the certainties, especially when we try to clarify causes of, and ascertain the responsibilities for, the attack. Regarding the causes, direct causes cannot be established, although we can stress some factors which may have contributed to this climate of hostility. A couple of factors have been pointed out as the main triggers of the assault. The first was the assassination of Abu Yahya al-Libi, a Libyan citizen who assumed important responsibilities in Al Qaeda, in Pakistan in June 2012. To avenge his death, the day before the attack, the leader of Al Qaeda, the Egyptian Al-Zawahiri (Burton \& Katz, 2013, p. 23) called for attacks on Western interests in East Libya. The second factor was the release of Innocence of Muslim, a film that provoked a feeling of outrage throughout the Muslim world (Lowenberg, 2013, p. 353). "Spontaneous protests" erupted against U.S. diplomatic facilities in different cities of the world, particularly in cities such as Cairo or Karachi (Dodman, 2015, p. 25). Although neither the video nor the killing could be considered as real causes 
of the assault, their influence should be considered when explaining what happened in Benghazi.

If we focus on the attack on the U.S. consulate in Benghazi, we see that the assault can be divided into two different stages: The first one occurred at 9:40 $\mathrm{PM}$ and the second at 4:00 PM.

- The First Strike: At 9:00 p.m. Ambassador Stevens retired to his room. Forty minutes later, a group of 125-150 militants charged against the main gate of the U.S. Consulate. The U.S. Senate Select Committee on Intelligence clarified that there were no protests previous to the assault. Ambassador Stevens called the Embassy in Tripoli to communicate that they were under attack. The attackers entered the main building and set fire to the consulate that was protected by only nine people (four Libyan security agents and five diplomatic security agents). Ambassador Stevens and Information Officer Sean Smith were secured in a haven by Special Agent Scott Strickland. The main building was filled with smoke and Strickland jumped through the window, but Stevens and Smith remained inside. Three agents came back and looked in the main building for Smith and Stevens. They looked for Smith's corpse but could not find it. He was eventually found by a group of Libyans who entered the compound later. He was rushed to the Benghazi Medical Centre where he was administered CPR for an hour and a half. Despite these attempts to resuscitate him, Ambassador Stevens died of asphyxiation (Babin \& Tyrrell 2014, p. 25).

- The Second Strike: Around 1:00 a.m. a rescue team coming from the U.S. Embassy in Tripoli arrived in Benghazi. The team moved over 30 Americans from the consulate building to the CIA annex. At that time, President Obama, Hillary Clinton, and Leon Panetta had already been informed of the situation. At 4:00 a.m. a second attack, now against the CIA building, began. The attackers launched an assault on the CIA building, killing Glen Doherty and Tyrone Woods. This second attack ended at 4:15 p.m.. At 10:00 a.m. the bodies of Ambassador Stevens, Smith, Doherty and Woods left Benghazi heading for the United States (via Bennina and Ramstein).

The Benghazi assault cannot be considered an isolated incident. On the contrary, the attack could be considered a more or less generalized reaction to Western policies towards the Middle East. Other Western diplomatic delegations were also victims of these uncontrolled groups. These are the cases of the U.S. embassies in Yemen, Egypt, and Afghanistan, the British delegation in Khartoum, or the Spanish mission in Tunisia and in Kabul, where two policemen were killed. 
Today, there is a great debate regarding whether the Libyan tragedy could have been prevented or not, given the fact that many warning signals were sent from the world of intelligence bureaux. However, one wonders whether the consulate in Benghazi met the safety standards established in the Crowe and Inman reports.

\section{The Commission of Inquiry (Accountability Review Board)}

Before analyzing the inquiry commission that deals with the case of Benghazi, we will evaluate whether the U.S. Consulate met the standards set in the Owen and Inman Reports.

Despite rumors about the safety of the Benghazi Consulate, one issue has been stressed in the hearings of the U.S. Congress: The attack on the consulate was unprecedented, and therefore, it could not have been prevented. If we go deeper into the recommendations of the Inman and Crowe reports and compare this information with the conditions of the building of the consulate, we appreciate that the compound met most of the recommendations made in both reports:

(1) First, the main consulate building was far from the town or the busy streets, as the Inman report recommended. In this way, it would be easier to avoid commercial areas or busy roads.

(2) Second, as required by the State Department, the consular compound did not share walls with adjacent buildings or privately-owned country estates or farmlands. This element has proved to be decisive in the safety of diplomatic and consular buildings.

(3) Thirdly, following the Inman and Crowe reports, it was also positive for the security of the mission that the complex was exclusively dedicated to the State Department, thus eliminating the need to share it with another entity.

(4) Fourth, following recommendations for diplomatic buildings after the bombings in Tanzania and Kenya, the consular compound consisted of two large buildings instead of only one.

(5) Fifth, the main buildings were located over 30 metres away from the outer fence, a measure specifically recommended by the Inman report. Thus, any car bomb attack or similar would have been impossible because the target of the attack was located far enough to be able to repel it.

However, some aspects of the security of the U.S. Consulate could have been improved following the recommendations of the Inman and Crowe reports, especially the outer walls. Some of the images published after the tragedy show that the walls of the complex seemed to be thinner than 
suggested ( 0.5 meters $)$ and probably also lower than the minimum recommended height (3 meters).

Another much-criticized factor was the custody of the main entrance. In principle, in any embassy, access used to be under the responsibility of local security forces. In Benghazi, the situation was no different, and the main entrance of the consulate was guarded by Libyan forces backed by U.S. security personnel.

In its weekly communication, the U.S. Embassy warned that Libyan security forces could remain faithful to the old regime. Specifically, the Militia of February 17, the forces in charge of guarding the consulate, have been accused of not acting properly during the assault on the consulate. However, the regional security officer in Tripoli, Eric. A. Nordstrom, said that given the ferocity of the attack, it could not have been repelled with a dozen extra agents.

However, the fragmentation of security in Eastern Libya after the fall of Qhadaffi has caused insecurity. Nowadays, security is divided into different factions led by warlords who have earned their legitimacy by contributing to the fall of the previous regime. That is why the United States has not accredited any first level head of mission and, for the moment, has accredited only two chargés d'affaires.

As required by the Omnibus Diplomatic and Antiterrorism Act of 1986, the attack on the U.S. Consulate in Benghazi is being investigated by the Foreign Affairs Committee. The inquiry commission-the Accountability Review Board-has been co-chaired by two eminent figures for U.S. policy:

- Admiral Mike Mullen, who has served as Chief of Staff, was particularly critical of the management of the State Department. He even stated that, at certain levels, leadership and management skills had failed.

- Thomas Pickering is a U.S. diplomat with extensive international experience especially in the Middle East (Pickering, 2010, pp. 57-63). Like Mullen, Pickering was particularly critical of the performance of the State Department, saying that it was inadequate and that the forces guarding the delegation were overrun by a heavily armed militant group.

In addition to the two co-chairs, the commission was also composed by representatives of other security agencies. Among the members of the commission, we can highlight:

- Catherine Bertini, an American official, who has held positions of representation during the Reagan and George $\mathrm{H}$. Bush administrations. Today she works for Maxwell University.

- Richard Shinnick is a State Department official who was responsible for the safety of diplomatic and consular buildings. He became director ad 
interim of the body that ensures their safety: The Bureau of Overseas Buildings Operations (OBO).

- Hugh Turner is a CIA official in charge of different issues related to security of buildings of diplomatic delegations.

It is important to point out the uniqueness of the situation lived during those days in the Southern Mediterranean and the Middle East. On September 11, 2012, several U.S. delegations in the region-Yemen, Turkey, and Tunisia-were under attack. Focusing on the case of Libya, when the first signs of attacks appeared, the secretary of state contacted both the Embassy and the Libyan authorities. The first decision was clear: The Department of State ordered the access of the consulate to be closed.

In spite of that, the secretary of state was accused of acting too slowly. However, before the Senate Committee, she stated that there were "No delays in decision making." Under Secretary for Management Paul F. Kennedy defended what he considered correct decisions of the secretary of state during the crisis, denying any delay during this period of time. In the same vein, the secretary of state pointed out that while that hearing was being held, a dozen attacks against diplomatic delegations were taking place in different places in the world. In fact, just one week later, the U.S. Embassy in Ankara was the object of a suicide attack that killed three security guards working in an adjacent building. The embassy facilities did not suffer any damage, thus confirming the effectiveness of the new designs of delegation. However, although these measures allow a defense against attacks, they cannot prevent attacks, because as the secretary of state John Kerry explained in his farewell speech we live in very dangerous times.

As a sign of this riskiness, other diplomatic missions have become a prime target of terrorists in Libya after the Benghazi tragedy. As we see in Table 1, many embassies have been attacked in Libya in the last two years.

Table 1. Terrorist attacks in Libya against diplomatic missions.

\begin{tabular}{lllcc}
\hline Date & Embassy of & City & Deaths & Injuries \\
\hline 2013 & France & Tripoli & 0 & 0 \\
June 25, 2013 & UAE & Tripoli & 0 & 0 \\
June 29, 2013 & Pakistan & Tripoli & 0 & 0 \\
October 3, 2013 & Russia & Tripoli & 3 & 0 \\
November 13, 2014 & Egypt & Tripoli & 0 & 0 \\
November 13, 2014 & UAE & Tripoli & 0 & 0 \\
January 17, 2015 & Algeria & Tripoli & 0 & 3 \\
February 22, 2015 & Iran & Tripoli & 0 & 0 \\
April 12, 2015 & South Korea & Tripoli & 2 & 1 \\
April 13, 2015 & Morocco & Tripoli & 0 & 0 \\
April 21, 2015 & Spain & Tripoli & 0 & 0 \\
June 12, 2015 & Tunisia & Tripoli & 0 & 0 \\
\hline
\end{tabular}


In any case, the Benghazi Accountability Review Board in the unclassified report published on December 18, 2012 acknowledged that the responsibility for the attack rests entirely with the terrorists who perpetrated the assault. However, the report admitted substantial failures in the decisions made during the crisis and overall significant security shortfalls. Following the board statement, the State Department gave insufficient priority to the Benghazi mission's security.

\section{Extraordinary measures adopted after the Benghazi attack}

The Benghazi attack, as happened after the bombings against the U.S. facilities in Beirut (1986) and East Africa (1998), has led to the adoption of a series of exceptional measures. These measures, based on the ARB's recommendations, can be divided into actions to be taken by the State Department and legislative proposals to be adopted by the U.S. Congress.

\section{State Department actions in response to the Benghazi terrorist attack}

Due to the failures detected in leadership and management, the State Department removed four employees from their positions. At the time of the attack, three of these officials were working for the Bureau of Diplomatic Security and the other one for the Bureau of Near Eastern Affairs.

The Accountability Review Board published an unclassified report that included a total of 29 recommendations and 64 measures. These recommendations are grouped into six large blocks, whose shared aim is to make all the U.S. diplomatic facilities safer: (a) overarching security considerations, (b) staffing high risk, high threat posts, (c) training and awareness, (d) security and fire safety equipment, (e) intelligence and threat analysis, and (d) personnel accountability.

We can highlight the following most significant measures: First, there has been an increase in the personnel dedicated to providing security for diplomatic facilities and staff. Following an ARB's recommendation, the State Department has increased the diplomatic security personnel. In FY2013, the State Department hired 113 diplomatic security personnel and another 38 in FY2014. Second, the State Department reorganized its Diplomatic Security Bureau creating a new position-deputy secretary for high threat post-to supervise security arrangements in high-risk countries. In 2014, the State Department, through the deputy secretary for high threat post, identified a total of 30 high threat posts. Third, the State Department established a protocol-vital presence validation process (VP2) - to assess the security situation and to implement a plan for the return of the diplomatic staff in these high risk/high threat areas. Fourth, the department has created a tool 
called "support cells" to implement procedures before opening or re-opening high threat/high-risk posts. The State Department has used VP2 and support cell procedures have been applied in the return to the U.S. mission in Bangui (Central African Republic) in 2014. Fifth, the State Department has increased its cooperation with the Department of Defense deploying Marine security guard detachments in high threat/high posts.

Finally, the ARB recommended the creation of two independent panels to conclude the inquiry on the Benghazi attack: The Best Practice Panel and The Panel of Outside Experts. The Best Practice Panel was chaired by Mark Sullivan, a diplomat who had previously worked as a director of the U.S. Secret Service. The panel suggested the implementation of 38 measures, the most important of which was the creation of an under secretary for security to upgrade a function that today belongs to a lower level, the under secretary for management. The State Department considered that this proposal might be counterproductive, although they accepted 30 out of 38 recommendations.

The second panel proposed by the ARB-The Panel of Outside Expertsfocused its activity on the State Department organization. Chaired by former Under Secretary of State Management Grant Green, the members of the panel addressed a report to the under secretary of state for management in May 2013. This report is not public, but the State Department has accepted most of its recommendations.

To ensure the compliance with these objectives, the ARB asked for a budget increase for the security of diplomatic facilities during FY2013, FY2014, and FY2015. In this sense, a total of US $\$ 1.419$ billion were allocated to the Increased Security Proposal (ISP), a new program essentially focused on security (Table 2).

\section{Legislative response to the Benghazi terrorist attack}

Since the Benghazi attack, the U.S. Congress has been working intensively on the safety of embassies and diplomatic personnel. The legislative power has been very active organizing hearings, commissions of inquiry, and especially publishing reports on this concrete issue. In particular, during the 112th and 113th Congresses, a total of seven reports were focused directly or indirectly on this incident (Table 3).

Table 2. Increased Security Proposal (ISP).

\begin{tabular}{lc}
\hline & Million US\$ \\
\hline 35 detachments of Marine Security Guards (225 marines) & 553 \\
155 Diplomatic Security personnel (high threat/high risk post) & 130 \\
Upgrade of security facilities and construction of new U.S. embassies & 736 \\
\hline
\end{tabular}

Source: Alex Tiersky, "Securing U.S. Diplomatic Facilities and Personnel Abroad: Legislative and Executive Branch Initiatives," Congressional Research Service, December 23, 2014. 
Table 3. U.S. Congress reports on the Benghazi attack.

\begin{tabular}{|c|c|c|c|}
\hline Report & Chairman & Released by & Date \\
\hline $\begin{array}{l}\text { Flashing Red: A special report } \\
\text { on the Terrorist Attack at } \\
\text { Benghazi }\end{array}$ & $\begin{array}{l}\text { Joseph Lieberman } \\
\text { and Susan Collins }\end{array}$ & $\begin{array}{l}\text { U.S. Congress, Senate Committee on } \\
\text { Homeland Security and } \\
\text { Governmental Affairs }\end{array}$ & $\begin{array}{l}\text { December } \\
30,2012\end{array}$ \\
\hline "Interim Progress Report" & $\begin{array}{l}\text { H. McKeon, E. } \\
\text { Royce, B. Goodlate, } \\
\text { D. Isa, and M. } \\
\text { Rogers. }\end{array}$ & $\begin{array}{l}\text { Committee on Armed Service; } \\
\text { Committee on Foreign Affairs; } \\
\text { Committee on the Judiciary, } \\
\text { Committee on Oversight \& } \\
\text { Government Reform; Permanent } \\
\text { Select Committee on Intelligence. }\end{array}$ & $\begin{array}{l}\text { April 23, } \\
2013\end{array}$ \\
\hline $\begin{array}{l}\text { Benghazi Attack: Investigative } \\
\text { Update; Interim Report on } \\
\text { the Accountability Review } \\
\text { Board }\end{array}$ & Darell Isa & $\begin{array}{l}\text { U.S. House of Representatives, } \\
\text { Committee on Oversight and } \\
\text { Government Reform }\end{array}$ & $\begin{array}{l}\text { September } \\
16,2013\end{array}$ \\
\hline $\begin{array}{l}\text { Review of the Terrorist Attacks } \\
\text { on US Facilities in Benghazi, } \\
\text { Libya }\end{array}$ & $\begin{array}{l}\text { Diane Feinstein and } \\
\text { Saxby Chambliss }\end{array}$ & $\begin{array}{l}\text { U.S. Congress Senate Select } \\
\text { Committee on Intelligence }\end{array}$ & $\begin{array}{l}\text { January } 15, \\
2014\end{array}$ \\
\hline $\begin{array}{l}\text { Benghazi: Where is the State } \\
\text { Department Accountability? }\end{array}$ & Ed Royce & $\begin{array}{l}\text { Majority Staff of the House Foreign } \\
\text { Affairs Committee }\end{array}$ & $\begin{array}{l}\text { February 7, } \\
2014\end{array}$ \\
\hline $\begin{array}{l}\text { Majority Interim Report: } \\
\text { Benghazi Investigation } \\
\text { Update }\end{array}$ & $\begin{array}{l}\text { Howard P. "Buck" } \\
\text { McKeon }\end{array}$ & $\begin{array}{l}\text { House Armed Service Subcommittee } \\
\text { on Oversight and Investigations }\end{array}$ & $\begin{array}{l}\text { February } \\
10,2014\end{array}$ \\
\hline $\begin{array}{l}\text { Investigate Report on the } \\
\text { Terrorist Attack on US } \\
\text { facilities in Benghazi }\end{array}$ & $\begin{array}{l}\text { Mike Rogers and } \\
\text { Dutch } \\
\text { Ruppersberger }\end{array}$ & $\begin{array}{l}\text { House Permanent Select Committee } \\
\text { on Intelligence }\end{array}$ & $\begin{array}{l}\text { November } \\
21,2014\end{array}$ \\
\hline
\end{tabular}

Concerning the diplomatic legislation, the 113th Congress has approved two bills related to embassy security and its personnel. The first one is the H.R. 2848 (FY2014) that authorized investing US $\$ 4.78$ billion to improve security at the embassy compounds through the programs Embassy Security, Construction and Maintenance (ESCM) and Worldwide Security Protection. The second one is the S. 1386 (FY2014) that provided the Capital Security Cost Sharing Program with an extra line of $\$ 1.386$ billion (Tiersky, 2014). This second initiative also grants US $\$ 5$ million for language training for security personnel in high-threat, high-risk posts.

\section{Conclusions}

One of the lessons we have learned in Benghazi is that absolute security simply does not exist. We live in an increasingly dangerous world where weak and failed states serve as training centers for militants of violent groups. These groups blame other countries, especially the West, for the situation in which they live. Very often, these militants are unable to travel abroad to attack the far enemy (Booth \& Dunne, 2012, p. 31), and thus the diplomatic and consular delegations become achievable targets. Among all the diplomatic delegations, U.S. embassies are the most attractive for these violent groups. While it is true that the United States has always been a target for 
violent actions, since the September 11, 2001 terrorist attack, terrorist attacks have soared exponentially.

The Benghazi attack has revolutionized terrorism against diplomatic delegations. The methodology of the assault has taken most of the ministries of foreign affairs by surprise. A group of heavily armed men stormed into a building with the only intention of killing as many people as possible. Unfortunately, Benghazi was neither the first nor the last attack of this nature. In 2009, the terrorist group Lashkar-e-Taiba attacked different targets in the Indian city of Mumbai. Since then, there have been similar terrorist attacks in different parts of the world.

Focusing on the Benghazi case, this terrorist attack has revolutionized diplomatic security. The security measures adopted, many of them following the recommendations of the Crowe and Inman Reports, could not stop the attack against the U.S. Consulate. As happened before with the cases of Tehran, Lebanon, and East Africa, the assault on the U.S. Consulate has given rise to a paradigm shift (the third one) in the protection of the diplomatic facilities. The mode of operation has been the same as in the previous cases.

(1) First, a terrorist attack that casts doubt on the security of diplomatic missions occurs.

(2) Second, a commission of inquiry that analyses the case and proposes measures is created.

(3) Third, the State Department takes action that change the way the U.S. protects its diplomatic missions

The United States has focused its response to the Benghazi attacks in three main areas: transparency, warning, and security.

(1) Transparency: Apart from the Accountability Review Board the House of the Congress has created seven commissions of inquiry to discover what failed in Benghazi and how to prevent further attacks in the future.

(2) Warning: The State Department is reconfiguring protocols for risk assessment in its embassies. Among other measures, perhaps the most remarkable one has been the creation of the Vital Presence Validation Process (VP2). This protocol has been tested on the U.S. mission to the Central African Republic.

(3) Security: The Obama administration significantly increased funding for the protection of diplomatic facilities. In this sense, the State Department is increasing the security staff at the embassies (diplomatic security personnel and Marine guards) to protect the diplomats in high risk/high threat posts. Finally, it should be mentioned that the State Department will continue with the construction of the oft-named 
"fortress embassies." To overcome this alienation, the Obama administration passed the "Stand with Civil Society" initiative that aims to bring American diplomacy closer to societies of the receiving states (Lagon \& Grebowski, 2015, p. 47).

In conclusion, it must be said that the Benghazi attack has caused the third paradigm shift in the always brittle relationship between security and diplomacy. This shift seeks to provide more security for diplomats but at the same time, it complicates their daily work. Unfortunately, the Benghazi attack confirmed a trend that began just after the September 11, 2001 terrorist attack. U.S. diplomatic missions are more similar to a bunker than to an embassy. Many American diplomats may be accredited abroad for a period of four years without leaving the embassy compound. Under these circumstances, the diplomatic institution has an increasingly bleak future in the United States and perhaps in the rest of the world.

\section{Acknowledgments}

I wish to thank Prof. Susan Jeffrey for her valuable comments on a previous draft.

\section{Notes}

1. According to Buzan's (1991, pp. 432-433) definition on security.

2. According to Watson's (1982, p. 11) definition on diplomacy.

3. Article 41 of Vienna Convention on Diplomatic Relations.

4. "The ferocity and intensity of the attack was nothing that I had seen in Libya or that I had seen in my time in the Diplomatic Security Service. Having an extra foot of wall or an extra-half dozen or agents would not have enabled us to respond to that kind of assault. I am concerned that this attack will signal a new security reality just as the 1984 Beirut attack did for the Marines; the 1998 East Africa bombing did for the State Department and the 9/11 for the whole country." Prepared Statement Eric A. Nordstrom. "Hearing on Security Failures in Benghazi," House of Representatives, 12 October 2012, p. 2.

5. The terrorist attack against the Marines barracks and the U.S. Embassy in the Lebanon was investigated by a commission of inquiry chaired Admiral Bobby Ray Inman.

6. Apart from the Inman report the government adopted other measures like the Public Access Control Program, The Security Enhancement Program, the 1982 Security Supplemental, or the FY-1985 Security Supplement.

7. The Crowe report was the result of the commission of inquiry into the attacks in Kenya and Tanzania.

8. The Government of the United States created other agencies like the Overseas Security Advisory Council (OSAC), the Diplomatic Security Service (DSS), or the Bureau of Diplomatic Security (BDS). 


\section{Notes on contributor}

Alberto Priego holds a Ph.D. from Complutense University (International Relations). He currently is a Senior Lecturer at the Universidad Pontificia de Comillas in Madrid, where he has been a faculty member since 2010. His research interests lie in the areas of Middle East Studies, Islam, and Diplomacy. He has collaborated actively with researchers in several other disciplines of history, economy, and political science. During 2007-2009 he was postdoctoral fellow at SOAS (The University of London).

\section{ORCID}

Alberto Priego (i) http://orcid.org/0000-0001-5627-9563

\section{References}

Abad, G. (2015). El concepto de seguridad: Su transformación. Comillas Journal of International Relations, 2(4), 41-51.

Babbin, J., \& Tyrrell, E. (2014). Whitewashing Benghazi: Nothing to see here, folks. Move along. American Spectator, 47(2), 24-27.

Berridge, G. R. (2010). Diplomacy: Theory and practice (4th ed.). Basingstoke, UK: Palgrave MacMillan.

Booth, K., \& Dunne, T. (2012). Terror in our time. Abingdon, UK: Routledge.

Bullock, J. L. (2015). Keeping embassy security in perspective. The Foreign Service Journal, 92 (4), 33-38.

Burton, F., \& Katz, S. (2013). The untold story of the attack in Benghazi under fire. New York, NY: Icon.

Busa, E. (2006). U.S. restores diplomatic relations with libya. Foreign Service Journal, 83(7-8), $13-14$.

Buzan, B. (1991). New pattern of global security in the 21st century. International Security, 67(3), 423-433.

Buzan, B. (2007). People, states and fears. Colchester, UK: ECPR Press.

Buzan, B., \& Hansen, L. (2009). The evolution of international security studies. Cambridge, UK: Cambridge University Press.

Campbell, R. (2008). Sending the wrong message to the rest of the World. Architectural Record, 196(10), 61-62.

Dodman, M. (2015). Effective diplomacy after Benghazi. The Foreign Service Journal, 92(4), 24-27.

Ferrell, R. H. (1975). American diplomacy. New York, NY: Norton \& Company.

Hanson, T. (2012). The traditions and travails of career diplomacy in the United States. In P. Sharp \& G. Wiseman (Eds.), American diplomacy (pp. 199-217). Leiden, The Netherlands/ Boston, MA: Martinus Nijhoff Publishers.

Houghton, D. P. (2013). The decision point. Six cases in the U.S. foreign policy decision making. Oxford, UK: Oxford University Press.

Inman, R. B. (1985, June). Report of the Secretary of State's advisory panel on overseas security. Retrieved from https://1997-2001.state.gov/www/publications/1985inman_report/inman1.html

Jentleson, B. W., \& Whytock, C. A. (2005). Who won Libya? The force-diplomacy debate and its implications for theory and policy. International Security, 30(3), 47-86. doi:10.1162/ 016228805775969582 
Kosowatz, J. J. (2002). Balancing security, visibility takes U.S. mission to suburbs. Engineering News-Records, 249(13), 17-19.

Lagon, M., \& Grebowski, S. (2015). Time for societal diplomacy. The National Interest, 136, $39-47$.

Loeffler, J. C. (2004). The American embassy: Design excellence vs. security? Architectural Record, 192(7), 67-69.

Loeffler, J. C. (2007, September-October). Fortress America. Foreign Policy, 54-57.

Lowenberg, B. (2013). The U.S. as a benevolent international Leviathan. Houston Journal of International Law, 35(2), 323-358.

Paoletti, E. (2011). Libya: Roots of a civil conflict. Mediterranean Politics 16(2), 313-319.

Patman, R. G. (2012). U.S. foreign policy in Africa. In M. Cox \& D. Stokes (Eds.), U.S. foreign policy (pp. 297-314). Oxford, UK: Oxford University Press.

Pickering, T. R. (2010). The United States, Iran, and the Greater Middle East. American Foreign Policy Interests, 32(2), 57-63. doi:10.1080/10803921003697534

Pigman, G. A. (2010). Contemporary diplomacy. Cambridge, UK: Polity Press.

Pillar, P. R. (2001). Terrorism and U.S. foreign policy. Washington, DC: Brookings Institution Press.

Pope, L. (2015). The demilitarization of American diplomacy. Two cheers for striped pants. Basingtoke, UK: Palgrave MacMillan.

Quainton, A. C. E. (2015). Diplomatic security triage in a dangerous world. The Foreign Service Journal, 92(4), 29-33.

Rana, K. S. (2013). The contemporary embassy. Basingstoke, UK: Palgrave MacMillan.

Ros-Lehtinen, I. (2012). Did the Obama administration do enough to provide security for the U.S. Consulate in Benghazi, Libya? International Debates, 10(9), 41-46.

Rowe, W. (1999, January). Report of the Accountability Review Board on the embassy bombing in Nairobi and Dar es Salaam. Retrieved from http://adst.org/wp-content/uploads/2012/08/ Accountability-Review-Board-on-U.S.-Embassy-Nairobi-bombing.pdf

Tan, A., \& Ramakrishna, K. (2002). The new terrorism. Anatomy, trends and counterstrategies. Singapore: Eastern University Press.

Tiersky, A. (2014, December 23). Securing U.S. diplomatic facilities and personnel abroad: Legislative and executive branch initiatives. Retrieved from https://fas.org/sgp/crs/row/ R43195.pdf

United Nations (1961). Vienna Convention on Diplomatic Relations. Retrieved from http:// legal.un.org/ilc/texts/instruments/english/conventions/9_1_1961.pdf

United Nations. (1963). Vienna Convention on Consular Relations. Retrieved from http:// legal.un.org/ilc/texts/instruments/english/conventions/9_2_1963.pdf

Watson, A. (1982). Diplomacy. The dialogue between the states. London, UK: Eyre Methuen.

Watson, A. (1987). Hedley bull, states systems and international societies. Review of International Studies, 13(2), 147-153. doi:10.1017/S0260210500113701 